\title{
Formation and development of professional competencies of municipal employees who manage agricultural production on the territory of municipalities
}

\author{
Bayrta Ubushayeva ${ }^{1 *}$, Natalia Bykovskaya ${ }^{2}$ and Sanji Koteyev $^{3}$ \\ ${ }^{1}$ State University of management, 109542, Ryazan Ave., 99, Moscow, Russia \\ ${ }^{2}$ Russian state agrarian correspondence University, 143907, Moscow region, Balashikha, shosse \\ Entuziastov str., 50, Russia \\ 3AIAPI named after A. A. Nikonov-branch of The Federal research center for agricultural Economics \\ and social development of rural territories-ARIAE, 107078 Bolshoy kharitonevsky lane, 21, p. 1, \\ Moscow, Russia
}

\begin{abstract}
The article analyzes the formation and development of professional competencies of municipal employees who manage agricultural production in local territories. In the article, the authors present options for the possible development of the competencies of municipal employees, which is based on the division of professional competencies into three groups, thereby dividing them by functionality. Basic competencies set requirements for the level of education, municipal service experience, or professional experience. Functional competencies are established according to the direction of the Department, and special ones are formed specifically for each position of the municipal service in the Department that manages agricultural production on the territory of the municipality. The content of the article makes it possible to expand the range of professional competencies based on the use of certain measures that are necessary for municipal employees to fill positions in the studied branch of the economy.
\end{abstract}

\section{Introduction}

In the context of the strategic guidelines of the Russian state, one of the priorities is agricultural production. Along with technological, production and other tasks of the agricultural sector, the Central subjects are municipal employees who organize favorable conditions for agricultural production in the territories of municipalities. Therefore, at present, the objective criteria in the system of municipal management are the competencies on the basis of which the strategic implementation of state tasks in the system of agricultural production in rural areas will take place.

\footnotetext{
${ }^{*}$ Corresponding author: ubgyy@bk.ru
} 
Currently, the" professional competencies " of an employee in a particular management system Express:

1) the employee's ability to act according to certain standards;

2) personal qualities and characteristics that make it possible to achieve results in a particular activity.

According to V. A. Gnevasheva [1] the category" competence " includes either the quality of a person, or the knowledge, skills and abilities.

In the research of foreign specialists, the following logic of speculation is noted in relation to the category "competence, which is expressed in the specific ability to effectively perform specific actions in the subject area, including narrow-subject knowledge, special subject skills, ways of thinking, understanding of responsibility for their actions". [2] thus, the competence category has social and professional significance.

The main goal of the development of professional competencies of municipal employees is actions that will help residents and business entities to solve certain tasks. Also, the core of the professional competence of a municipal employee consists of values and recognized rules of behavior based on both official norms and ethical ones.

One of the main activities of the municipal service is management, which is important in assessing professional competencies.[9] Municipal employees must be professional managers, so they must have managerial knowledge, professional skills and abilities. The professional competence of municipal employees who fill various positions in the municipal service depends largely on the strategic goals of the municipality and the subject of the Russian Federation, as well as the priorities of a specific advantage. In this case, the relationship between the content of professional competencies and the strategic goal is as follows: the level of efficiency of municipal employees depends on their ability to make correct management decisions, improve the quality of municipal services and ensure their availability to residents and business entities.

Thus, it can be concluded that the activities for the formation and development of professional competencies of municipal employees should cover all stages of development of the municipal employee as a person.

\section{Materials and methods}

In order to assess the level of development of professional competencies of municipal employees who manage agricultural production in local territories, it is necessary to identify certain requirements for competencies, dividing them into three groups.

1) group 1 is the basic competence that is unified for all positions of the municipal service. They usually contain requirements such as knowledge of the Russian language, knowledge of legislation, knowledge of electronic document management, knowledge and ability to work in the operating system, knowledge and compliance with ethics, ability to build relationships with colleagues, knowledge of business communication style, etc.

2) group 2 is a functional competence that is formed based on the specifics of the direction and specialization of the activities of the local government, the duties of which are performed by employees of various categories and groups of positions.

These include such requirements as the skills of document management related to the direction of activity, knowledge of procedures for preparing orders, orders, knowledge of official labor regulations, knowledge of the collective agreement, knowledge of methods for analyzing work related to their activities, etc.

3 ) group 3 is a special competence that is determined based on the types of work of a municipal employee in a particular position.

These competencies are expressed in the ability to analyze the state of activities carried out by the municipal service, skills and knowledge of conducting expertise, skills to work 
with various sources of information, the ability to determine the structure of work, the ability to effectively and efficiently distribute and use human time, skills in preparing requests and responses, managerial skills, etc.

Practice shows that the real assessment of professional competencies of municipal employees who manage agricultural production is difficult due to the lack of a clear understanding of the content and classification of competencies into basic, functional and special. To assess the competencies of municipal employees, certification is used. [6]

In General, the certification evaluates the quantity and quality of work and functions performed, their complexity, novelty, and overall performance over the estimated period (three years). When conducting certification of municipal employees who manage agricultural production (municipal district, rural settlement), the results of the execution of official regulations, professional knowledge in the field of organization and management of the agricultural sector, compliance with restrictions, the absence of violations and prohibitions are taken into account.

Evaluating the application of certification, we can draw a similar conclusion: in this case, there is no real and objective assessment of the professional competencies that a particular municipal employee possesses. The reason, in our opinion, is that managers at all levels in the local government administration do not have a clear understanding of the content and classification of competencies into basic, functional and special.

Analyzing the application of existing professional competence assessment processes, we can say that currently there is no clear system of criteria for evaluating the professional competence of municipal employees who manage agricultural production on the local territory. The regulatory legal documents of most municipalities do not establish the classification of professional competencies by groups and do not define the processes for evaluating professional competencies, which creates certain problems in the implementation of personnel technologies.

The problems we have identified in assessing the professional competence of municipal employees who manage agricultural production allow us to conclude that there is no competence approach in the assessment. In order to be effective in managing agricultural production, it is necessary to use the professional competencies of municipal employees in the assessment, which are able to assess not only the generally accepted (basic), but also functional and special professional competencies. To solve these problems, it is necessary to create a passport of professional competencies of municipal employees and methodological tools for assessing professional competencies.

\section{Results and discussion}

The purpose of this passport is to make effective and objective decisions when assessing the level of professional competencies that should be possessed by municipal employees who manage agricultural production. Similarly to the passport of professional competencies developed for municipal employees who manage agricultural production, passports can also be developed for other municipal employees who are responsible for other industrial areas on the territory of municipalities.[3] The same approach can be applied for further development of tools for diagnostics of professional competencies.

Table 1. Requirements for professional competencies (basic, functional, special) of the leading specialist of the Department for agricultural production management

\begin{tabular}{|c|c|}
\hline $\begin{array}{c}\text { Duties of the leading specialist of the Department } \\
\text { of agricultural production management }\end{array}$ & $\begin{array}{c}\text { Requirements for professional competence of the } \\
\text { leading specialist of the Department of } \\
\text { agricultural production management }\end{array}$ \\
\hline 1 & 2 \\
\hline \multicolumn{2}{|c|}{ Basic professional competencies } \\
\hline
\end{tabular}


Compliance with the norms of official behavior based on the norms of Federal legislation, the subject of the Russian Federation, the municipality, and business etiquette

Preparation of documents in accordance with the established requirements using modern office equipment

Maintaining an electronic document management system, carrying out office work with the use of IT technologies

\begin{tabular}{|l}
\hline $\begin{array}{l}\text { Business communication with colleagues, } \\
\text { citizens }\end{array}$ \\
\hline
\end{tabular}
Functional competencies
Implementation of works (functions) in activity population on the activities of the Department
Ability to apply the norms of the Constitution of the Russian Federation, the Federal law "on municipal service in the Russian Federation", the Code of official and ethical conduct of a municipal employee

Ability to apply the instructions for working with documents in the local government when preparing the necessary documents and implement document management procedures, use office equipment

Ability to use IT-programs, maintain databases, apply IT-technologies; conduct business in its own direction in accordance with the approved nomenclature of the Department

Ability to effectively communicate with colleagues, citizens; make clear oral messages;

Ability to carry out work (functions) in accordance with the direction of the Department's activities based on the application of the Federal law "on the development of agriculture" from 29.12.2006 N 264-FZ, the Land Code, the Civil Code, etc.

Ability to explain to residents and farmers the tasks and functions of the Department and to consider in a short time written and oral proposals, applications received from legal entities and individuals on issues within the competence of the Department

\section{Special competencies}

Registration of sale and lease agreements for land plots, as well as agreements on extending lease terms, or on making additions and changes to contracts

Ability to prepare documentation for the organization of auctions for the sale of land plots in compliance with established procedures. The ability to prepare information for requests from organizations and citizens, to compile reports in accordance with established rules and procedures

Provision for approval of draft resolutions on the provision of land plots for ownership or lease Ability to prepare municipal legal acts and coordinate them in accordance with established procedures: draft resolutions on the provision of land plots, benefits and subsidies;

Maintaining a register of various programs and projects that stimulate agricultural production on the territory of the municipality

Ability to maintain a register of targeted programs and projects, both Federal and regional, in accordance with the established rules

Given the large volume of development, we offer a passport of professional competencies (basic, functional, special) only for the leading specialist of the Department of administration for agricultural production management within the average municipal district. [5]

For a basis we take authority in the management of agricultural production on the territory of the municipality set out in the Charter of the MO, work (function) is enshrined in official regulations leading specialist of the administration of the agricultural production. [4]

Based on the analysis of these materials, we will design requirements for its basic, functional, and special professional competencies (table 1) 
Table 2. Tools for assessing the competencies of municipal employees of the Department that manages agricultural production

\begin{tabular}{|c|c|c|}
\hline $\begin{array}{c}\text { Duties of the leading specialist } \\
\text { of the Department of } \\
\text { agricultural production } \\
\text { management }\end{array}$ & $\begin{array}{l}\text { Requirements for professional } \\
\text { competence of the leading } \\
\text { specialist of the Department of } \\
\text { agricultural production } \\
\text { management }\end{array}$ & $\begin{array}{l}\text { Method of assessment of } \\
\text { professional competencies }\end{array}$ \\
\hline 1 & 2 & 3 \\
\hline \multicolumn{3}{|c|}{ Basic professional competencies } \\
\hline $\begin{array}{l}\text { Compliance with the norms of } \\
\text { official behavior based on the } \\
\text { norms of Federal legislation, the } \\
\text { subject of the Russian } \\
\text { Federation, the municipality, } \\
\text { and business etiquette }\end{array}$ & $\begin{array}{l}\text { The ability to apply the } \\
\text { provisions of the Constitution } \\
\text { of the Russian Federation, } \\
\text { Federal law "On municipal } \\
\text { service in the Russian } \\
\text { Federation", Laws of subjects } \\
\text { of the Russian Federation, } \\
\text { Charter of a municipal Code } \\
\text { official and ethical conduct of } \\
\text { the municipal employee }\end{array}$ & $\begin{array}{l}\text { Test of knowledge of the } \\
\text { legislation of the Russian } \\
\text { Federation, laws of subjects } \\
\text { of the Russian Federation, } \\
\text { normative legal acts of a } \\
\text { municipality }\end{array}$ \\
\hline $\begin{array}{l}\text { Preparation of documents in } \\
\text { accordance with the established } \\
\text { requirements using modern } \\
\text { office equipment }\end{array}$ & $\begin{array}{l}\text { Ability to apply the instructions } \\
\text { for working with documents in } \\
\text { the local government when } \\
\text { preparing the necessary } \\
\text { documents and implement } \\
\text { document management } \\
\text { procedures, use office } \\
\text { equipment }\end{array}$ & $\begin{array}{l}\text { Test for knowledge of } \\
\text { document flow rules, } \\
\text { database management rules, } \\
\text { and rules for maintaining } \\
\text { the list of cases; }\end{array}$ \\
\hline $\begin{array}{l}\text { Maintaining an electronic } \\
\text { document management system, } \\
\text { carrying out office work with } \\
\text { the use of IT technologies }\end{array}$ & $\begin{array}{l}\text { Ability to use IT-programs, } \\
\text { maintain databases, apply IT- } \\
\text { technologies; conduct business } \\
\text { in its own direction in } \\
\text { accordance with the approved } \\
\text { nomenclature of the } \\
\text { Department }\end{array}$ & $\begin{array}{l}\text { Case studies to identify } \\
\text { skills for organizing and } \\
\text { planning work time; } \\
\text { Practical task for skill } \\
\text { assessment }\end{array}$ \\
\hline \multicolumn{3}{|c|}{$\begin{array}{ll}\text { Functional professional competencies } \\
\end{array}$} \\
\hline $\begin{array}{l}\text { Implementation of works } \\
\text { (functions) in accordance with } \\
\text { the direction of the } \\
\text { Department's activity }\end{array}$ & $\begin{array}{l}\text { Ability to perform work } \\
\text { (functions) in accordance with } \\
\text { the Department's activity based } \\
\text { on the application of the norms } \\
\text { of Federal law No. 264 "on } \\
\text { agricultural development" dated } \\
29.12 .2006 \text {, the Land Code, the } \\
\text { Civil Code of the Federal law } \\
\text { of the Russian Federation dated } \\
29 \text { July } 1998 \text { No. 135-FZ "on } \\
\text { appraisal activities in the } \\
\text { Russian Federation", various } \\
\text { normative legal acts of the } \\
\text { municipality }\end{array}$ & $\begin{array}{l}\text { Test for knowledge of the } \\
\text { functions, goals and } \\
\text { objectives of the } \\
\text { Department of agricultural } \\
\text { production management }\end{array}$ \\
\hline $\begin{array}{l}\text { Implementation of work on } \\
\text { consideration of written and } \\
\text { oral proposals, applications } \\
\text { received from legal entities and } \\
\text { individuals on issues within the } \\
\text { competence of the Department }\end{array}$ & $\begin{array}{l}\text { Ability to consider written and } \\
\text { oral proposals, applications } \\
\text { received from legal entities and } \\
\text { individuals on issues within the } \\
\text { competence of the Department } \\
\text { for agricultural production } \\
\text { management on the territory of } \\
\text { the municipality }\end{array}$ & $\begin{array}{l}\text { Cases for evaluating the } \\
\text { skills needed to review } \\
\text { offers from businesses and } \\
\text { individuals to the } \\
\text { Department }\end{array}$ \\
\hline
\end{tabular}




\begin{tabular}{|c|c|c|}
\hline \multicolumn{3}{|c|}{ Special professional competencies } \\
\hline $\begin{array}{l}\text { Preparation of necessary } \\
\text { documents for making decisions } \\
\text { on granting land plots for } \\
\text { ownership, } \\
\text { (indefinite) use, gratuitous use, } \\
\text { lease to citizens and legal } \\
\text { entities }\end{array}$ & $\begin{array}{l}\text { Ability to apply the norms of } \\
\text { the Land Code, the Civil Code, } \\
\text { Federal laws regulating land } \\
\text { relations, laws of the subjects } \\
\text { of the Russian Federation } \\
\text { regulating land relations, the } \\
\text { Charter of a municipality }\end{array}$ & $\begin{array}{l}\text { Test the knowledge of the } \\
\text { norms of the Land code, } \\
\text { Civil code, Federal laws } \\
\text { regulating land relations, } \\
\text { and laws of constituent } \\
\text { entities of the Russian } \\
\text { Federation regulating land } \\
\text { relations as well as } \\
\text { normative legal acts of } \\
\text { municipal formation }\end{array}$ \\
\hline $\begin{array}{l}\text { Preparation of documentation } \\
\text { on the organization of } \\
\text { participation of residents and } \\
\text { business entities in grants that } \\
\text { stimulate agricultural } \\
\text { production in the territory of the } \\
\text { municipality }\end{array}$ & $\begin{array}{l}\text { Ability to prepare } \\
\text { documentation on the } \\
\text { organization of participation of } \\
\text { residents and business entities } \\
\text { in grants that stimulate } \\
\text { agricultural production in the } \\
\text { territory of the municipality in } \\
\text { compliance with established } \\
\text { procedures }\end{array}$ & $\begin{array}{l}\text { Cases on skills of preparing } \\
\text { information for requests } \\
\text { from organizations and } \\
\text { citizens in accordance with } \\
\text { the established rules }\end{array}$ \\
\hline
\end{tabular}

The next task is to develop methodological tools that will allow for an objective assessment of the municipal employee who manages agricultural production, as well as to form an objective order for improving the skills of municipal employees, taking into account the need to improve the necessary professional competencies. [7]

In the Toolkit, we suggest using the following methods: interview, questionnaire, testing for specific professional knowledge, psychological testing, solving cases, writing an abstract or essay (table 2).

In our opinion, the described tools should be fixed by the normative acts of municipalities, [8] in particular, and changes should be made to the regulations "on certification of municipal employees in local government bodies", the regulations" on holding a competition for positions of municipal service", the regulations" on the personnel reserve of municipal service positions " and the official regulations of municipal employees of the Department for agricultural production management.

\section{Conclusions}

The implementation of this project will help the administration's personnel service to improve the existing methods of evaluation used during the competition for filling vacant positions of the municipal service of local territories, during certification, when sending for advanced training, when conducting a competition for inclusion in the personnel reserve.

In addition, the main result of the creation and implementation of the passport of professional competencies of municipal employees who manage agricultural production should be a qualitative assessment of the professional competencies of municipal employees. The developed tools will help you choose the most appropriate assessment method for each competence, as well as create your own tools by analogy for each Department position. [4]

The process of improving the methods of assessing the professional competence of municipal employees of the Department of agricultural production management of the local territory is important not only in the formation of professional personnel, but also the effectiveness of providing services to residents and business entities of the Department. In other words, there will be an improvement in the provision of municipal services and 
improved interaction with residents and businesses of various organizational and legal forms.

\section{References}

1. V. A. Gnevasheva, Youth of Russia: features of professional formation (2017) URL: http://www.mosgu.ru/

2. R.N. Galiakhmetova, Theoretical aspects of competence-based professional formation of an individual in Russian education

3. V. B. Zotov, Municipal akazhemia, 1, 111-120, (2019)

4. V. V. Ivanov, B. G. Ubushaeva, Great digital extinction of cultures, Trust. Risks: Trust in migration processes. Risks of a new society (2019)

5. F. M. Ibyatov, E. G. Khmelchenko, Municipal Academy, 4 (2019)

6. T. A. Vasileva, N. V. Varlamova, Institutions of public power in the context of globalization, 203-205 (M.: Norm, 2020)

7. S. V. Namysov, Labor potential as the most important factor of the organization's efficiency, Materials of the international scientific conference Economics of modern society: current issues of anti-crisis management (Elista, 2016)

8. T. T. Tsatkhlanova, D. V. Idzhilova, N. A. Burkutbaeva, Economy and entrepreneurship, 11, part 1(64-1), 319-322 (2015)

9. Oksana Thomova, Olga Petrina, Michael Stadlin, Natalia Klim-Eremina, Tatiana Matyas, International transaction journal of engineering, management and applied Sciences and technologies, 11A01J (2020) 